\title{
RAGAM HIAS BINATANG DALAM MEDALION
}

\author{
Kirno *)
}

\begin{abstract}
Indian - Indonesia culture acculturation played a riddle which still debated until today. Indian cultural influence was strong in Central Java and inversely proportional to the area of East Java. At the temple, the visual form change was easily found where the form of towering slender turned into fat and wide. The concentric form change to chtonis system, human decorations that look realistic style turned into puppets as one of the characteristics of prehistoric cultures. Decorative variety of medallions as one of ornament in Induk Panataran Temple are a visual text that attempts to convey a message. Animal species diversity engraved in Decorative variety of medallions became an evidence of the local genius skills in blending and gathering the Indian cultural influences for the future.
\end{abstract}

Keyword : Ornament, Medallion, Panataran Temple, Local Genius

\section{Pendahuluan}

Ragam hias merupakan salah satu hasil kebudayaan yang dimiliki setiap peradaban manusia. Kebudayaan lahir dari buddhi atau akal manusia sebagai makhluk tertinggi. Penyebaran ragam hias tersebut menurut Van Der Hoop terbagi menjadi dua yakni penyebaran difusi atau dari satu pusat yang menyebar dan "Elementargedanken" atau kesamaan fikiran dari tiap manusia di belahan bumi yang berjauhan (Hoop, 1949: 9) Elementargedanken dapat dijelaskan sebagai sebuah pemikiran yang muncul secara serentak atau hampir bersamaan dalam wilayah yang berbeda.

Candi Panataran merupakan suatu kompleks percandian yang terbesar di Jawa Timur (Wiyadi, 1982: 88). Candi Panataran ditemukan pada tahun 1815 oleh Sir Thomas Stamfort Raffles (1781 - 1826), letnan gubernur jendral kolonial Inggris yang berkuasa di Indonesia. Candi Induk Panataran dihiasi dengan relief yang dipahatkan pada panel-panel vertikal dipisahkan satu dengan yang lain oleh sebuah medalion, masingmasing dengan seekor binatang berbeda yang dikelilingi oleh stilisasi dedaunan (Holt, 2000: 102). Ragam hias medalion pada Candi Induk berjumlah delapan puluh dengan ragam hias binatang di dalamnya. Penempatan binatang sebagai hiasan dalam bangunan suci tersebut menjadi menarik untuk dikaji apakah terdapat makna simbolis ataukah karena pengaruh orang India di mana dalam pemujaan seharihari memuja tiga dewa yakni Gramadewata (dewa desa atau kota), Kuladewata (dewa keluarga), Istadewata (dewa perorangan), pemujaan binatang, pemujaan kepada tumbuh-tumbuhan, pemujaan kepada roh jahat dan pemujaan tempat ziarah (Harun, 1975: 34).

\footnotetext{
* Kirno (sirno_san@yahoo.com), Staff Pengajar Lembaga Pendidikan Anak Usia Dini FastrackFunschool Yogyakarta
} 
Local genius bangsa Indonesia dalam menerima pengaruh kebudayaan India memiliki keunikan tersendiri sehingga nilainilai yang sudah ada menjadi semakin matang bahkan bersinar hingga mencapai tingkat klasik. Percampuran kebudayaan tersebut terdiri dari berbagai bidang, seperti agama dan kesenian. Dalam bidang seni bentuk seni sastra, seni bangun, patung dan seni hias merupakan seni yang berkembang dengan 1.

\section{Pembahasan}

Kata "candi" adalah sebutan lain atau nama lain "Dewi Durga" dalam kaitannya dengan "Dewi Maut" yakni "Dewi Candi" atau "Dewi Candika". Untuk memuja dewi tersebut dibuatkanlah bangunan atau rumah yang dalam bahasa Sansekerta adalah grha. Bermula dari sanalah kemudian berubah menjadi kata Candika grha yang berarti 'rumah dewi candika' yaitu bangunan kuil untuk tempat pemujaan kepada Dewi Candika (Haryono, 2001: 1). Kata "Panataran" berasal dari bahasa Sansekerta pa-natha-ayrya-an. Kata nata berarti 'pemimpin' atau 'raja', kata ayrya berarti 'melukiskan sesuatu yang dipersonifikasikan pada orang berkedudukan tinggi'.

Dalam disertasinya mengenai candi

yang berjudul "Candi Fungsi dan Pengertiannya", Soekmono berpendapat bahwa candi merupakan bangunan pemujaan (kuil). Mengacu kepada pendapat Soekmono, hiasan yang ada di dalam candi tentunya selain berfungsi sebagai nilai hias juga memiliki maksud tertentu sebagai wujud kecintaan kepada yang dipuja.

Binatang sebagai makhluk yang dekat dengan kehidupan manusia dapat diklasifikasikan menjadi tiga, yaitu: binatang yang bermanfaat dalam kehidupan umum, baik. Telah diakui bahwa keberadaan masyarakat Indonesia telah memiliki kebudayaan sendiri sebelum datangnya kebudayaan India. Masuknya kebudayaan India pada akhirnya membawa beberapa ahli Indonesia belajar ke India. Barnet Kempers mencatat bahwa para ahli yang pulang dari tanah India tidak serta-merta mengadopsi seni India namun telah mengolahnya menjadi seni dengan gaya tersendiri binatang yang merugikan dan dapat merusak tanaman, binatang yang berguna tetapi dapat juga menimbulkan penyakit (Dwiyanto, 1988: 4).

\section{Binatang dalam Medalion Candi Induk Panataran}

Zaman keemasan Hindu dan Buddha hingga saat ini menyisakan bukti-bukti cukup kuat yang menunjukkan hubungan antara seni dan religi. Salah satu dari hasil kebudayaan tersebut adalah keberadaan candi. Binatang merupakan salah satu jenis ragam hias yang sering digunakan di dalam bangunan candi. Ragam hias binatang secara simbolik terbagi menjadi dua golongan, yakni simbol dunia atas dan dunia bawah. Jenis burung merupakan wakil dari alam atas dan binatang darat berkaki empat atau melata merupakan simbol alam bawah.

Dengan mencermati data awal ragam hias medalion, penulis membagi jenis binatang dalam empat kelompok, yaitu binatang yang bermanfaat dalam kehidupan umum atau peliharaan, binatang liar, binatang perusak tanaman, serta binatang mitologi.

Untuk mempermudah analisis, hasil pencermatan dibuat dalam bentuk tabel di bawah ini : 
Tabel I. Nama Binatang dan Kategori

\section{No. Nama Binatang}

\section{Kategori}

1. Peliharaan

2. Liar

3. Perusak

4. Mitologi

Tanaman

1. Ayam Jago (Gallus Sp.)

2. Badak Cula Satu (Rhinoceros

Sondaicus)

3. Bebek (Anatidae)

4. Babi Liar (Sus Scrofa)

5. Kancil (Tragulus Napu)

6. Kasuari (Casuarius Casuarius)

7. Kuntul (Egretta Sp.)

8. Kuntul (Bubalus Bubalis)

9. Kijang (Muntiacus Muntjae)

10. Luwak (Paradoxurus

Hermaproditus)

11. Landak (Hystrix Brachyura)

12. Puyuh (Turnix Sp.)

13. Rangkong (Buceros Sp.)

14. Rusa (Cervus Sp.)

15. Tupai (Sciurus Sp.)

17. Angsa (Cygnus Sp.)

18. Antelope (Boselaphus

Tragocamelus)

19. Anjing (Canis Familliaris)

20. Buaya (Crocodylidae)

21. Kelinci (Lepus Negricollis)

22. Biri-Biri Jantan (Ovis Aries)

23. Banteng (Bos Javanicus)

24. Bayan (Eclectus Roratus)

25. Burung Hantu (Ketupa Ketupu)

26. Burung Cuckoo (Cuculus Canorus)

27. Falcon (Falco Sp.)

28. Garangan (Ophiophagus)

29. Gajah (Elephas Maximus)

30. Kuda (Equus Caballus)

31. Kucing (Felis Domesticus)

32. Keledai (Equus Asinus)

33. Lingsang (Lutra Sp.) 


\begin{tabular}{llcccc}
\hline 34. & Merpati (Columba Livia) & $\checkmark$ & $\checkmark$ & - & - \\
\hline 35. & Merak (Pavo Muticus) & $\checkmark$ & - & - & - \\
\hline 36. & Macan (Panthera Tigris) & - & $\checkmark$ & - & - \\
\hline 37. & Sapi (Bos Taurus) & $\checkmark$ & - & - & - \\
\hline 38. & Tikus (Rattus Sp.) & - & - & $\checkmark$ & - \\
\hline 39. & Ular (Serpens) & - & $\checkmark$ & - & - \\
\hline 40. & Naga Liman & - & - & - & $\checkmark$ \\
\hline 41. & Kambing (Capra Sp.) & $\checkmark$ & - & - & - \\
\hline & Persentase & $34,2 \%$ & $51,2 \%$ & $12,2 \%$ & $2,4 \%$ \\
\hline
\end{tabular}

Keterangan tabel:

1. Binatang Bermanfaat dalam Kehidupan Umum atau Peliharaan

2. Binatang Liar

3. Binatang yang Menimbulkan Penyakit serta Merusak Tanaman

4. Binatang Mitologi

Dilihat dari jenisnya, binatang liar lebih banyak digunakan sebagai ragam hias. Keberadaan binatang yang sulit ditemukan tentu merupakan peliharaan yang spesial dari sesorang. Secara tidak langsung hal tersebut dapat memberikan nilai lebih bagi pemiliknya. Binatang yang bukan berasal dari wilayah Jawa membuktikan bahwa telah terjalinnya hubungan antaretnik pada masa itu. Ini dibuktikan dengan adanya jenis burung Kasuari yang bukan binatang dari Jawa. Kasuari merupakan jenis binatang yang hidup di daerah Indonesia timur dan Australia.

Binatang berbadan, seperti kuda dan berkepala kombinasi naga dan gajah merupakan satu-satunya binatang mitologi yang digunakan sebagai ragam hias pada medalion Candi Induk Panataran. Binatang ini hampir memiliki kesamaan bentuk dengan kereta Kasultanan Cirebon Paksi Naga Liman. Berdasarkan mitos yang berkembang bahwa binatang Paksi Naga Liman merupakan simbol dari tiga kebudayaan yang berpengaruh di Cirebon, yaitu Cina, Islam, dan Hindu.

\section{Simbolisasi Ragam Hias Binatang}

Manusia merupakan makhluk yang berbeda dengan makhluk lainnya di muka bumi. Perbedaan ini terletak pada sebuah sistem yang tidak dimiliki binatang. Hal ini di sebut sebagai system symbol, sehingga manusia disebut juga animal symbolicium (Cassier, 1990: 40). Sebagai penghuni alam raya, manusia menuangkan seluruh gagasan dan ide ke dalam bentuk konsep dan kemudian menjadi simbol-simbol tertentu. Simbol menjadi alat komunikasi dalam perilaku sehari-hari, sehingga hal tersebut menjadi salah satu penyebab munculnya kebudayaan manusia.

Simbol merupakan tanda berdasarkan konvensi, peraturan, atau perjanjian yang disepakati bersama (Tinarbuko, 2008: 17). Simbol hanya disepakati oleh kelompok secara komunal, sehingga simbol tidak berlaku bagi kelompok yang lain. Simbol yang ditinggalkan manusia dari masa lalu sebagian besar merupakan simbol yang berkaitan dengan religi atau agama. Menurut Spredley, terdapat tiga fungsi simbol: pertama mengurangi persepsi-persepsi secara individu, kedua sebagai tanda syarat yang diketahui, ketiga sebagai pembangkit minat orang untuk menambah pengetahuan yang baru (Susanto, 2001:497). 


\section{Ayam Jantan}

Sifat Ayam Jantan yang senantiasa berkokok bersama matahari pagi menjadi lambang dari matahari. Dalam masyarakat Jawa, ayam jantan disebut juga jago. Ayam ini sering menjadi binatang aduan, sehingga menjadi lambang dari keberanian dan kekuatan.

\section{Badak Cula Satu}

Badak dalam bahasa Jawa disebut warak. Kata warak satu akar kata dengan waras yang artinya 'sadar'. Dengan demikian, badak menjadi simbol dari kesadaran. Kesadaran di sini bertujuan untuk mencapai puncak tertinggi spiritual, sehingga hanya dengan kesadaran yang tinggi seseorang dapat mencapai puncak spiritual tertinggi.

\section{Bebek}

Bebek merupakan binatang yang hidup secara berkelompok, sehingga bebek memiliki simbol kasih sayang.

\section{Babi Liar}

Babi hutan merupakan salah satu binatang Awatara (penjelmaan), yakni ketiga penjelmaan dari Dewa Wisnu dalam agama Hindu. Awatara pertama adalah ikan kemudian kura-kura. Cerita mitos mengenai penjelmaan Wisnu menjadi babi hutan yang memiliki dua taring besar adalah ketika bumi akan dihancurkan oleh golongan Detya (raksasa) bernama Hiranyaksa. Wisnu kemudian menjelma menjadi babi hutan kemudian bertarung melawan Hiranysaksa. Setelah pertempuran yang cukup lama akhirnya Wisnu menang dan mengembalikan bumi dalam keadaan seperti semula. Babi liar merupakan perlambangan kehidupan darat (tanah) setelah kura-kura (hidup di dua alam), sedangkan ikan menjadi simbol kehidupan pertama (air). Babi liar menjadi simbol dunia bawah dan keperkasaan.

\section{Kancil}

Kancil merupakan binatang hutan yang habitat hidupnya jarang bersama manusia. Kancil seringkali dipergunakan sebagai perlambangan sifat kekanak-kanakan dan keingintahuan. Hal tersebut cukup dapat diterima karena seringkali kancil menjadi tanda akan hadirnya tamu yang datang dengan jeritnya. Kancil juga suka mengintip di balik sebuah pohon untuk melihat sesuatu dengan malu-malu.

\section{Kasuari}

Kasuari adalah jenis binatang yang tidak terdapat di Jawa. Kasuari berasal dari Kepulauan Aru, Papua, dan Australia, sehingga hal ini menjadi bukti bahwa hubungan antarwilayah pada masa kerajaan telah terjalin denga baik. Kasuari termasuk jenis burung yang tidak dapat terbang, sehingga menjadi simbol dari dunia bawah.

\section{Kuntul}

Kuntul merupakan binatang yang memiliki sistem migrasi atau perpindahan tempat sesuai musim. Panjangnya musim perpindahan menjadi lambang dari kehidupan yang panjang dan keabadian.

\section{Kijang}

Kijang sebgai binatang bertanduk dalam kepercayaan orang Jawa memiliki nama lain dhalang, menjadi lambang kegesitan dan kebijaksanaan. Kijang merupakan binatang yang cerdas. Tanduknya yang indah dikiaskan dalam alis pengantin perempuan Jawa, dengan harapan sebagai wanita dapat cerdas dan gesit dalam mengolah rumah tangga. Kijang juga sering muncul dalam cerita-cerita kuno seperti Ramayana maupun cerita fabel yang lain. Ini menjadi bukti bahwa Kijang merupakan binatang yang penting. 


\section{Musang}

Musang bagi mayarakat Jawa termasuk binatang pengganggu karena sering mencuri binatang peliharaan maupun telur ayam. Musang memiliki kemampuan observasi yang bagus sebagai binatang yang tangguh, sehingga menjadi lambang dari ketangguhan.

\section{Landak}

Landak merupakan binatang yang memiliki kulit duri. Binatang ini lebih sering berkegiatan di malam hari dari pada siang hari, mirip dengan burung Hantu. Melalui persamaan tersebut landak memiliki makna simbol yang sama, yakni simbol kematian. Landak juga termasuk binatang liar yang jarang dipelihara. Duri-durinya yang tajam akan berdiri apabila merasa dalam bahaya. Hal ini menjadi simbol akan kewaspadaan.

\section{Puyuh}

Burung Puyuh adalah jenis burung yang tidak dapat terbang seperti burung pada umumnya. Secara fisik Puyuh juga tidak memiliki ekor. Dalam mitos, burung Puyuh menjadi simbol wanita yang kurang baik. Burung puyuh secara alami memiliki kehidupan yang sama dengan Kasuari.

\section{Rangkong}

Rangkong memiliki nama lain burung Enggang. Burung ini menjadi lambang dari kematian dan kebangkitan kembali.

\section{Rusa}

Rusa merupakan binatang yang sejenis dengan kijang. Dalam hal ini, rusa juga memiliki karakter kijang.

\section{Tupai}

Tupai merupakan binatang yang sering merusak buah kelapa. Sebagai binatang liar, tupai sering membuat lubang untuk tempat tinggal maupun mencari makan. Tupai juga sering mengumpulkan makanan, sehingga tupai memiliki makna persiapan masa depan dan penghematan.

\section{Angsa}

Angsa termasuk populer dalam kebudayaan Hindu karena angsa merupakan binatang yaang menjadi salah satu vahana dewi, yakni Saraswati-Dewi Kesenian dan juga Brahma sebagai Dewa Pencipta. Bulu Angsa yang selalu kering dan purih meskipun berenang di air yang kotor menjadi lambang bahwa kebijaksanaan adalah sesuatu yang ada dalam kehidupan biasa tanpa terbawa atau tercemari urusan keduniawian.

\section{Antelope}

Dalam kebudayaan Hindu, binatang ini merupakan vahana Vayu-Dewa Angin. Dewa Vayu menurut mitos merupakan ayah guru dari Hanoman raja para kera yang cerdas. Antelope adalah binatang sejenis kijang namun memiliki tanduk berulir yang indah, sehingga menjadi simbol, seperti Kijang, yakni kelincahan, kegesitan, dan juga kecerdasan.

\section{Anjing}

Anjing bagi manusia termasuk binatang peliharaan. Keberadaan Anjing seringkali dimanfaatkan sebagai penjaga rumah maupun teman saat berburu. Dalam agama Hindu, anjing merupakan Vahana Brihaspati-Dewa Kesetiaan. Dengan demikian, anjing merupakan lambang dari kesetiaan. Anjing sebagai binatang yang senantiasa berdampingan dengan manusia telah muncul sejak lama. Salah satu cerita lama mengenai Mahabarata menyebutkan bahwa Dewa Indra pernah menjelma menjadi Anjing yang setia menemani Yudistira menuju Gunung Mahameru untuk mencari Swargaloka. Dewa 
Indra sendiri memiliki nama lain Swargapati atau Raja Surga.

\section{Buaya}

Buaya dalam kebudayaan Hindu merupakan vahana Ganga-Dewa Sungai Gangga. Buaya dikategorikan sebagai binatang melata atau reptil yang dalam kebudayaan Hindu mengacu kepada alam bawah dalam dualisme alam yang seimbang. Buaya menjadi simbol dari kesaktian yang luar biasa.

\section{Biri-Biri Jantan}

Biri-biri merupakan binatang peliharaan yang berguna bagi kehidupan manusia. Biri-biri dapat menghasilkan susu dan daging yang dapat dimakan. Dalam kebudayaan Hndu, biribiri merupakan Vahana Dewa Agni-Dewa api. Dewa Agni bergelar sebagai Dewa pemimpin upacara karena keahliannya dalam segala hal yang berkaitan dengan upacara keagamaan. Selain hal tersebut, nama lain dari Dewa Agni adalah Witihotra atau yang memberikan pahala kepada para penyembah. Dari hal ini, biri-biri jantan menjadi simbol dari kebaktian dan keberkahan

\section{Banteng}

Banteng Jawa merupakan salah satu binatang lokal yang digunakan sebagai ragam hias medalion. Banteng dalam penggambaran tidak jauh berbeda dengan sapi dan kerbau meskipun masih memiliki kemiripan namun penggunaan ragam hias ini memiliki makna yang berbeda. Kehidupan Banteng yang berkelompok membuat kawanan banteng menjadi kuat termasuk melindungi keluarga mereka dari serangan musuh. Banteng merupakan binatang agresif, sehingga menjadi lambang dari kekuatan, kemenangan, dan kejantanan.

\section{Bayan}

Dalam kebudayaan Hindu, burung ini merupakan vahana Dewa Kama-Dewa Asmara. Dalam visualisasinya sering kali burung ini membawa surat pada paruhnya sebagai pembawa kabar maupun pembawa surat-surat cinta. Burung ini menjadi lambang cinta kasih.

\section{Burung Hantu}

Dalam kebudayaan Hindu, burung ini memiliki hubungan erat dengan Dewi Lakshmi-Dewi Kemakmuran, Keberuntungan, dan Kemurnian. Burung ini selalu beraktivitas pada malam hari dan tidur saat siang hari. Dewi Keberuntungan membagikan kekayaan material maupun spiritual menggunakan kendaraannya, yaitu Uluka, sang burung hantu, sehingga burung hantu menjadi simbol keberkahan.

\section{Burung Cuckoo}

Burung ini memiliki fisik yang kecil dan memiliki suara yang indah. Burung Cuckoo juga merupakan vahana Kama-Dewa Asmara. Suaranya yang merdu dan kelincahannya menjadi lambang dari kegembiraan.

\section{Falcon}

Falcon merupakan burung satu ras dengan burung Elang yang dalam kebudayaan Hindu dekat dengan burung Garuda sebagai vahana Dewa Wisnu. Garuda dalam cerita Ramayana memiliki nama Jatayu sebagai lambang pembebasan.

\section{Garangan}

Garangan merupakan binatang yang dalam cerita Mahabarata muncul sebagai penyelamat Pandhawa saat cerita Bale Sigalagala. Garangan putih menjadi penuntun Bima untuk keluar dari rumah yang terbakar untuk menyelamatkan keluarga Pandhawa. 
Garangan putih merupakan penjelmaan Sang Hyang Antaboga. Garangan menjadi simbol dari kerja keras dan ketekunan

\section{Gajah}

Dalam agama Hindu, gajah dekat sekali dengan Ganesha, dewa dari ilmu pengetahuan dan kebijaksanaan. Dalam Hindu Sivaisme, gajah sering menjadi bagian dalam hiasan candi, ini merupakan simbol kejayaan hidup setelah kematian. Selain Ganesha, gajah juga menjadi salah satu Vahana dewa, yakni Dewa Indra (Dewa Perang, Dewa Petir, Raja Surga) dengan nama Airawata. Menurut mitologi Hindu, Airawata merupakan salah satu gajah penjaga alam semesta. la dianggap sebagai pemimpin para gajah. Dengan demikian maka gajah juga menjadi simbol dari kekuatan dan simbol kendaraan orang meninggal.

\section{Kuda}

Dalam kebudayaan Hindu, kuda merupakan binatang yang menarik kereta perang Dewa Surya-Dewa Matahari. Kuda merupakan salah satu binatang yang dalam keseharian membantu kehidupan manusia. Dengan demikian, kuda menjadi lambang kekuatan. Hingga saat ini pun daya kekuatan sebuah mesin atau motor diukur dengan satuan Kuda. Peran Kuda dapat disamaartikan dengan gajah dan kerbau sebagai kendaraan orang yang telah meninggal.

\section{Kucing}

Kucing merupakan jenis binatang mamalia dan menjadi peliharaan manusia. Kucing juga memiliki banyak anak ketika melahirkan serta senantiasa memberikan susu kepada anakanaknya. Secara fisik, kucing mirip sekali dengan macan. Dalam kebudayaan Hindu, kucing merupakan Vahana Dewi Shashti-Dewi Penjaga Anak-Anak, sehingga ini menjadi lambang dari penjaga, seperti juga dengan singa.

\section{Keledai}

Keledai merupakan binatang mirip kuda yang menjadi Vahana Nritti- Dewi Perusak di bagian barat daya. Nritti merupakan nama lain dari Laksmi ketika berubah menjadi Dewi Perusak, Kehancuran, Kesedihan. Nritti sering dikaitkan dengan Dewi Ratri (malam) karena malam membuat orang gelisah menjadi tenang dan tertidur serta istirahat dari kesedihan. Nritti termasuk bagian dari Dikpalas (Penjaga Delapan Arah) yakni dewa-dewa yang melindungi kuil utama candi. Yama, Nritti, Varuna, Kubera, Ishana, dan Indra adalah dewa yang menjaga kedelapan arah tersebut. Keledai sebagai binatang yang lamban ini menjadi salah satu simbol bahwa secara perlahan-lahan siapa pun akan merasakan kesedihan, kegelisahan, bahkan kehancuran.

\section{Lingsang}

Lingsang merupakan binatang yang sering hidup di sekitar sumber air. Dalam kebudayaan Hindu, binatang ini sering dipegang oleh Kuwera-Dewa Kekayaan, sehingga Lingsang merupakan lambang kekayaan.

\section{Merpati}

Dalam kebudayaan Hindu, merpati merupakan vahana Dewi Rati-Dewi Nafsu Seksual. Selain hal tersebut merpati juga binatang yang setia terhadap pasangan, sehingga merpati menjadi simbol dari kesetiaan.

\section{Merak}

Dewi Saraswati-Dewi Ilmu Pengetahuan dan Seni sering digambarkan bersama burung ini. Merak memiliki bulu yang indah, ekornya dapat mengembang besar melebihi badannya. Merak menjadi lambang kesombongan dan 
kebanggaan semu, dikarenakan keindahan bulu-bulu tersebut hanya sementara.

\section{Macan}

Dalam kebudayaan Hindu, macan merupakan vahana Ayyappan-Dewa yang merupakan anak dari Haran(Siva) dan Hari(Vishnu). Macan atau harimau dalam bahasa Sansekerta adalah wiagra, berasal dari kata wi (utama) dan agra (puncak), sehingga dengan demikian macan mengandung makna simbolis pencapaian puncak utama.

\section{Sapi}

Sapi dalam kebudayaan Hindu merupakan binatang yang suci karena merupakan vahana Dewa Shiva-Dewa Perusak. Dewa Shiva sering kali naik kendaraan sapi yang bernama Nandi. Sapi melambangkan kekuatan dan kejantanan selain itu sapi adalah simbol dari Ibu Mulia (Dewi Durga) yang memberikan makanan dan menjaga kehidupan. Simbol ini menyatakan bahwa susu sapi sama dengan susu ibu yang diberikan untuk anak-anaknya. Selain hal tersebut peranan Sapi dalam kehidupan sehari-hari sangat berguna, sehingga dapat meningkatkan kesejahteraan. Dari dasar hal tersebut seringkali sapi juga memiliki makna kesejahteraan dan kemakmuran. Sapi yang merupakan binatang peliharaan di dalam masyarakat Jawa menjadi lambang dari pengabdian, seperti kerbau.

\section{Tikus}

Dalam kebudayaan Hindu, tikus merupakan vahana Dewa Ganesa-Dewa Ilmu Pengetahuan dan Penghalau Segala Rintangan. Tikus merupakan binatang yang dapat menyelinap dimana saja dan mampu mengatasi hambatan atau rintangan, ini menjadi lambang orang yang berusaha mengatasi keinginan dan mengurangi sifat egoisnya.

\section{Ular}

Ular merupakan binatang melata yang menjadi penghuni alam bawah dalam dualisme alam semesta. Ular dalam penggambaran sendiri memiliki bentuk yang berbeda. Dalam kebudayaan Hindu, ular berkaitan dengan Dewi Manasa-Dewi Ular yang memberikan penawar terhadap semua racun ular. Ular menduduki posisi penting dalam kebudayaan Hindu, sehingga penghormatan terhadap ular begitu tinggi. Dewa Wisnu selalu bersantai di atas badan ular Shesha. Selain itu terdapat mitos bahwa bumi ini dijaga oleh kura-kura dan ular yang apabila ular bergerak menyebabkan gempa bumi. Berkaitan dengan makna simbolik, ular merupakan simbol dari keabadian. Hal ini dikarenakan ular mampu berganti kulit, sehingga seperti terlahir kembali. Bentuk ular yang melingkar dalam bentuk spiral menjadi simbol kelahiran kembali.

\section{Kambing}

Kambing dekat hubungannya dengan Pratiwi atau Dewi Sri. Dalam Purana dan Veda disebutkan bahwa benih yang jatuh dari Prajapati berubah menjadi kambing jantan. Dengan demikian, kambing memiliki makna kesuburan, kreativitas, kejantanan, kelimpahan, dan nafsu.

\section{Kerbau}

Kerbau merupakan binatang ternak, sehingga dalam kehidupannya dekat dengan manusia. Selain hal tersebut, kerbau memiliki banyak peran dalam usaha membantu kehidupan manusia, kerbau menjadi lambang dari dunia bawah kaitannya dengan dualisme pandangan kehidupan mengenai dunia atas dan bawah. Selain itu kerbau juga menjadi simbol dari pengabdiaan karena sifat kerbau yang jinak dan pasrah membantu kehidupan manusia. Kerbau juga memiliki fisik yang kuat, sehingga 
dapat mengangkut beban yang berat. Hal ini menjadi salah satu alasan mengapa kerbau disimbolkan sebagai kendaraan orang meninggal pada masa lalu.

\section{Binatang Berkaki Empat dan Bertelinga Lebar.}

Binatang berkaki empat, bertelinga lebar apabila diperhatikan mirip sekali dengan kelinci, sehingga penulis mendefinisikan bahwa binatang tersebut adalah kelinci meskipun dalam penggambarannya tidak semirip aslinya. Ketidakmiripan dengan binatang asli dapat disebabkan karena seniman pemahat belum pernah melihat binatang tersebut atau berdasarkan penuturan dari orang, sehingga dalam visualisasi bentuk menjadi tidak mirip. Hal ini juga terjadi dalam penggambaran singa. Di Indonesia singa merupakan salah satu jenis binatang yang sering digunakan sebagai penghias candi namun bentuknya jauh dari realistisnya.

\section{Binatang Berkaki Empat, Berkepala Naga, dan Berbelalai Gajah}

Binatang ini bagi orang Jawa sering disebut peksi (burung) naga (naga) liman (gajah), merupakan binatang mitologi yang terdiri atas gabungan beberapa jenis binatang yakni, kuda bersayap, gajah, dan naga. Ini menjadi sebuah usaha menggabungkan binatang yang mewakili segenap kekuatan alam. Naga menjadi simbol elemen air, gajah simbol elemen tanah, sedangkan peksi adalah simbol elemen udara.

Medalion merupakan salah satu bentuk ragam hias yang berupa ukiran-ukiran yang berbentuk bulat (Cardozo, tt: 21). Kata medalion dekat sekali dengan medali. Medali diberikan sebagai bentuk penghargaan atas jasa dan prestasi kepada seseorang atau kelompok tertentu. Medali yang berukuran besar disebut medalion sedangkan yang berukuran kecil disebut medalet (Atmojo, 2004: 24). Bentuk luar medalion adalah sebuah lingkaran, dalam agama Hindu hal itu disebut seperti mandala dan cakra. Bentuk dasar lingkaran menandakan sifat alam semesta yang tidak bertepi, mewakili sifat keabadian. Lingkaran yang kosong memberi makna mata atau mulut yang terbuka, lingkaran yang diberi titik di tengahnya yang menggambarkan matahari atau "mata" dari Penguasa Alam.

\section{Local Genius}

Haryati Soebadio mendefinisikan
local genius sebagai identitas atau
kepribadian budaya suatu bangsa, yang mengakibatkan, bahwa bangsa yang bersangkutan menjadi lebih mampu menyerap dan mengolah pengaruh kebudayan yang mendatanginya dari luar wilayahnya sendiri, sesuai dengan watak dan kebutuhan pribadinya (Soebandio, 1986: 19). Kebudayaan Indonesia asli yang belum terpengaruh oleh kebudayaan India terlihat pada masa prasejarah, pada masa tersebut bahasa, religi, seni, teknologi serta kelompok sosial telah kuat. Seiring dengan masuknya kebudayaan Hindu maka mulai terjadi percampuran antara budaya lokal dan budaya asing. Kebudayaan Hindu di Indonesia menstimulus berkembangnya kebudayaan lokal menjadi besar bahkan mencapai keemasan pada masa klasik. Soekmono menerangkan proses akulturasi kebudayaan India dalam sebuah diagram di bawah (Koentjaraningrat, 1986: 89). 


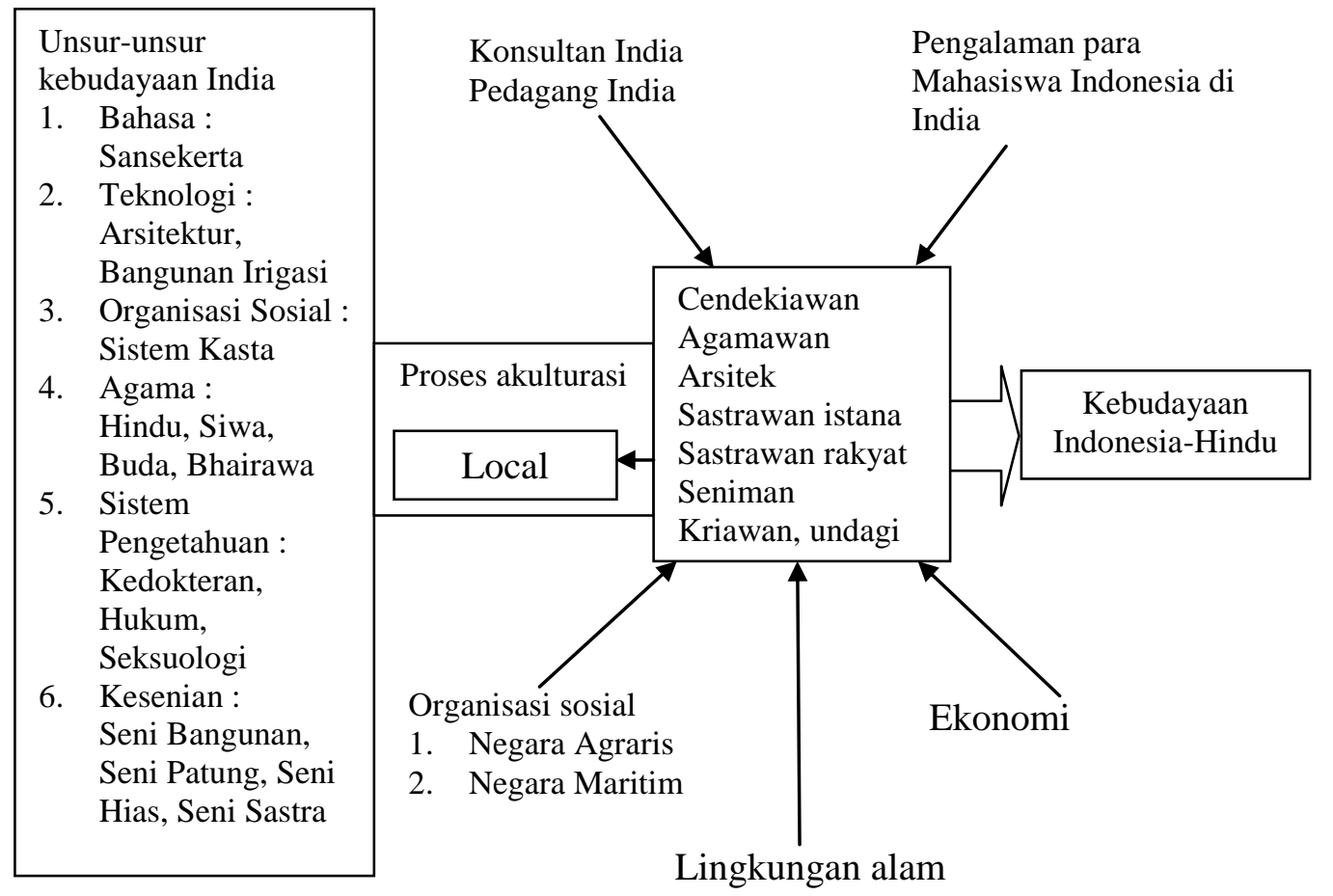

Gambar 17. Proses Akulturasi Kebudayaan India di Indonesia menurut Soekmono

Munculnya kembali local genius dalam masyarakat Indonesia merupakan salah satu bukti bahwa dalam proses percampuran kebudayaan, bangsa ini telah memiliki kebudayaan sendiri. Bangsa Indonesia yang lebih mengenal kontruksi bangunan dari bambu dan kayu belajar menggunakan kontruksi batu untuk pembuatan candi. Teknik pembuatan candi terdapat pada kitab Silpasastra, namun dalam kitab ini pemberian hiasan memang tidak memberikan ketentuan serta peraturan yang ketat, sehingga seniman lokal memanfaatkan kesempatan ini tanpa melanggar peraturan utama. Wiyoso Yudoseputro mengatakan bahwa identitas pada candi-candi di Jawa, khususnya di Jawa Timur menunjukkan peranan local genius yang mampu memberikan interpretasi terhadap kaidah-kaidah seni India berdasarkan landasan tradisi budaya Indonesia (Yudoseputro, 2005: 24). Dengan uraian di atas, peran local genius tidak dapat dikesampingkan dalam perkembangan kesenian pada umumnya dan seni bangunan candi khususnya di Indonesia. Penjelasan di atas memberikan kunci awal bahwa sebuah candi memiliki bentuk serta peran yang berbeda sesuai dengan kebutuhan masyarakat pendukungnya

Simbol dalam kebudayaan Hindu merupakan sesuatu yang begitu dekat dengan spiritualitas. Harus kita pahami bahwa simbol yang ada merupakan usaha untuk menghadirkan sesuatu yang bersifat religi ke dalam bentuk visual. Terdapat aturan-aturan khusus dalam pencitraan hal tersebut yang biasanya tertuang dalam kitab-kitab, seperti Chitrasutra (kitab untuk panduan lukisan), Silpasastra (kitab untuk pembuatan bangunan dan arca), Prathima Lakshana (aturan-aturan mengenai ikonografi). Kitab di atas tidak membatasi seniman namun memberikan keleluasaan dalam berekspresi dan berimajinasi. Kebebasan ekspresi memberikan ruang gerak kepada seniman di tengah-tengah aturan yang ada, sehingga dalam konteks ini seniman tidak melanggar mainstream tetapi 
dengan daya kreativitas yang tinggi mampu memberikan sesuatu yang baru dan indah

2. Seniman-seniman lokal memahami hubungan yang penting antara manusia dan alam, sehingga nilai-nilai tersebut berusaha untuk disampaikan melalui sudut pandang mereka. Manusia adalah bagian dari alam begitu juga dengan sebaliknya, tidak terdapat perbedaan yang nyata antara alam dan manusia (alam di sini termasuk binatang dan rumbuh-tumbuhan), sehingga seniman berusaha membuat simbol-simbol berdasarkan alam.

Di India kuno, binatang yang digunakan sebagai simbol terbagi menjadi binatang untuk berbagai keperluan seperti militer, komersial, rekreasi, atau sebagai obat. Dalam kitab Hindu disebutkan mengenai sapi, domba, kerbau, badak, keledai, gajah, burung, babi hutan, anjing, ular, harimau, dan binatang-binatang mitos. Sedangkan di sastra Jawa kuno memberikan informasi mengenai jenis fauna yang sering digunakan sebagai bahan simbolis oleh para kakawin ${ }^{3}$. Hal tersebut membuktikan peran penting hewan dalam kehidupan pada masa itu. Hal di atas memungkinkan perkembangan juga dalam ragam hias binatang. Ragam hias medalion pada candi Induk Panataran memiliki dua unsur, yakni unsur flora dan fauna yang terbingkai dalam lingkaran

Menurut Dwi Pradnyawan dalam melihat makna simbolis dari sebuah ragam hias candi, perlu melihat beberapa aspek, yakni kultur masyarakat saat itu dan fungsi dari candi ${ }^{4}$. Berbagai jenis binatang yang digunakan hingga saat ini belum dapat diketahui kepastiannya maksud dan tujuan dari penggunaan hiasan binatang-binatang tersebut meskipun dalam kebudayaan Hindu binatang-binatang tersebut dekat dengan vahana dewa-dewa ${ }^{5}$ tanpa mengesampingkan aturan yang ada

\section{Penutup}

Ragam hias medalion merupakan jenis ragam hias lepas yang tidak memiliki pengaruh terhadap struktur maupun bentuk utama candi. Binatang yang terdapat dalam medalion Candi Induk Panataran dalam perpektif Jawa dan Hindu memiliki makna khusus, sehingga mereka layak disematkan sebagai ragam hias di dalam candi. Pengaruh budaya Hindu di Jawa khususnya, menstimulus local genius untuk mengembangkan kebudayaan lokal tanpa menghilangkan budaya yang dimiliki sehingga memunculkan kebudayaan baru yang lebih kaya dan mencapai tingkat klasik.

Beberapa binatang dalam kehidupan manusia memiliki fungsi guna yang membantu manusia namun ada pula yang merugikan. Binatang liar yang tidak dipelihara dapat juga merupakan binatang koleksi sebagai lambang prestige seorang raja. Selain itu binatang yang tidak hidup di Jawa menjadi salah satu indikator telah terjalin kerja sama antarwilayah kerajaan pada masa lalu.

Munculnya binatang tersebut dalam ragam hias tentunya membutuhkan kajian yang lebih dalam lagi. Interpretasi mengenai hubungan hewan-hewan yang menjadi ragam hias dengan vahana dewa Hindu juga tidak dapat begitu saja diambil karena dalam dunia arkeologis perlu waktu dan kajian yang komprehensif mengenai sebuah benda hasil kebudayaan. Barnets Kampers yang menulis tentang seni Indonesia kuno juga memiliki catatan hampir lima puluh tahun tinggal di Indonesia untuk mengadakan penelitian khususnya dari tahun 1906 hingga 1956. Dengan demikian, hal ini baru merupakan sekelumit catatan yang dikumpulkan. 
${ }^{1}$ Satyawati Sulaiman. Lokal Genius pada Masa Klasik (baca : Kepribadian Budaya Bangsa (Local Genius), penyt. Ayatroheidi, Jakarta: Pustaka Jaya, 1986)

${ }^{2}$ N. Dasgupta menyebutkan bahwa dalam kenyataannya seniman memiliki pola pikir sebagai alat untuk menyampaikan sesuatu yang bersifat hakiki dan kekal. (baca : Fundamentals of Indian Art, Bharatiya Viota Bhavan Bombay Bhavan's Book University, 1951)

${ }^{3}$ P.J. Zoetmulder, menyebutkan berbagai jenis binatang yang sering digunakan sebagai kiasan simbolis seperti binatang Harimau, Badak, Kera, Burung Pelatuk, Gajah, Kuda, Kancil, Kijang, Beruang, Burung Cataka, Burung Helang, Merak, Burung Walik, Kuntul, Ayam alas dan yang lain-lain (baca: Kalangwan Sastra Jawa Kuno Selayang Pandang, Jakarta: Penerbit Djambatan, 1983)

${ }^{4}$ Dwi Pradnyawan, Dosen Arkeologi Universitas Gajah Mada Yogyakarta, Wawancara Pribadi.

${ }^{5}$ Meskipun dari hasil wawancara dengan Arkeolog Timbul Haryono menyebutkan bahwa tidak ada hubungan antara ragam hias binatang dalam medalion Candi Induk Panataran dengan vahana dewa bahkan dengan cerita Jataka atau cerita tentang binatang dalam kebudayaan Buddha meskipun sifat Candi Panataran adalah percampuran Hindu dan Buddha

\section{DAFTAR PUSTAKA}

Atmojo, Junus Satrio dkk. 2004. Vadamekum Benda Cagar Budaya, Kementerian Kebudayaan dan Pariwisata.

Ayatroheidi. 1986. Kepribadian Budaya Bangsa (Local Genius). Jakarta: Pustaka Jaya.

Bandi, dkk. 1984. Flora dan Fauna Dalam Ragam Hias. Jawa Timur: Proyek Pengembangan Permuseuman Jawa Timur.

Cassier, Ernst. 1990. Manusia dan Kebudayaan : Sebuah Esei tentang Manusia. Terj. Alois A. Nugroho, Jakarta: PT Gramedia.

Cardozo. S.L. tt. Seni India. Bandung: Balai Pendidikan Guru.
Dwiyanto, Djoko. 1998. “Arkeofauna sebagai Aspek Telaah Arkedekologi", Makalah Disampaikan pada Kegiatan Ilmiah Arkeologi IAAI Komisariat YogyakartaJawa Tengah , Yogyakarta.

Haryono, Timbul. 2001. "Peninggalan Bangunan Candi di Jawa", Makalah Ilmiah Disajikan pada Diklat Pramuwisata Propinsi Daerah Istimewa Yogyakarta.

Harun, Hadiwijono. 1975. Agama Hindu dan Buddha, Jakarta: Gunung Mulia.

Holt Claire. 2000. Melacak Jejak Perkembangan Seni di Indonesia. Bandung: Masyarakat Seni Pertunjukan Indonesia.

Hoop,Van Der. 1949. Indonesische Siermotieven, Ragam-ragam Perhiasan Indonesia, Indonesian Ornamental Design. Bandung : Koninklijk Bataviaasch Genootschap. Van Kusten En Wetenschappen.

Susanto, Nugroho. 2002. "Simbolisme dalam Arkeologi", dalam Kumpulan Makalah Pertemuan IImiah Arkeologi VIII, Jakarta.

Soedarmo, M. dan Wiyadi. 1982. Sejarah Seni Rupa Indonesia 3. Jakarta: Proyek Pengadaan Buku Pendidikan Menengah Kejuruan Departemen Pendidikan Dan Kebudayaan.

Tinarbuko, Sumbo. 2008. Semiotika Komunikasi Visual: Metode Analisis Tanda dan Makna pada Karya Desain Komunikasi Visual. Yogyakarta: Jalasutra.

Yudoseputro, Wiyoso. 2008. Jejak-jejak Tradisi Bahasa Rupa Indonesia Lama. Jakarta: Yayasan Seni Visual Indonesia. 
190 ] CORAK Jurnal Seni Kriya Vol. 1 No.2, November 2012-April 2013

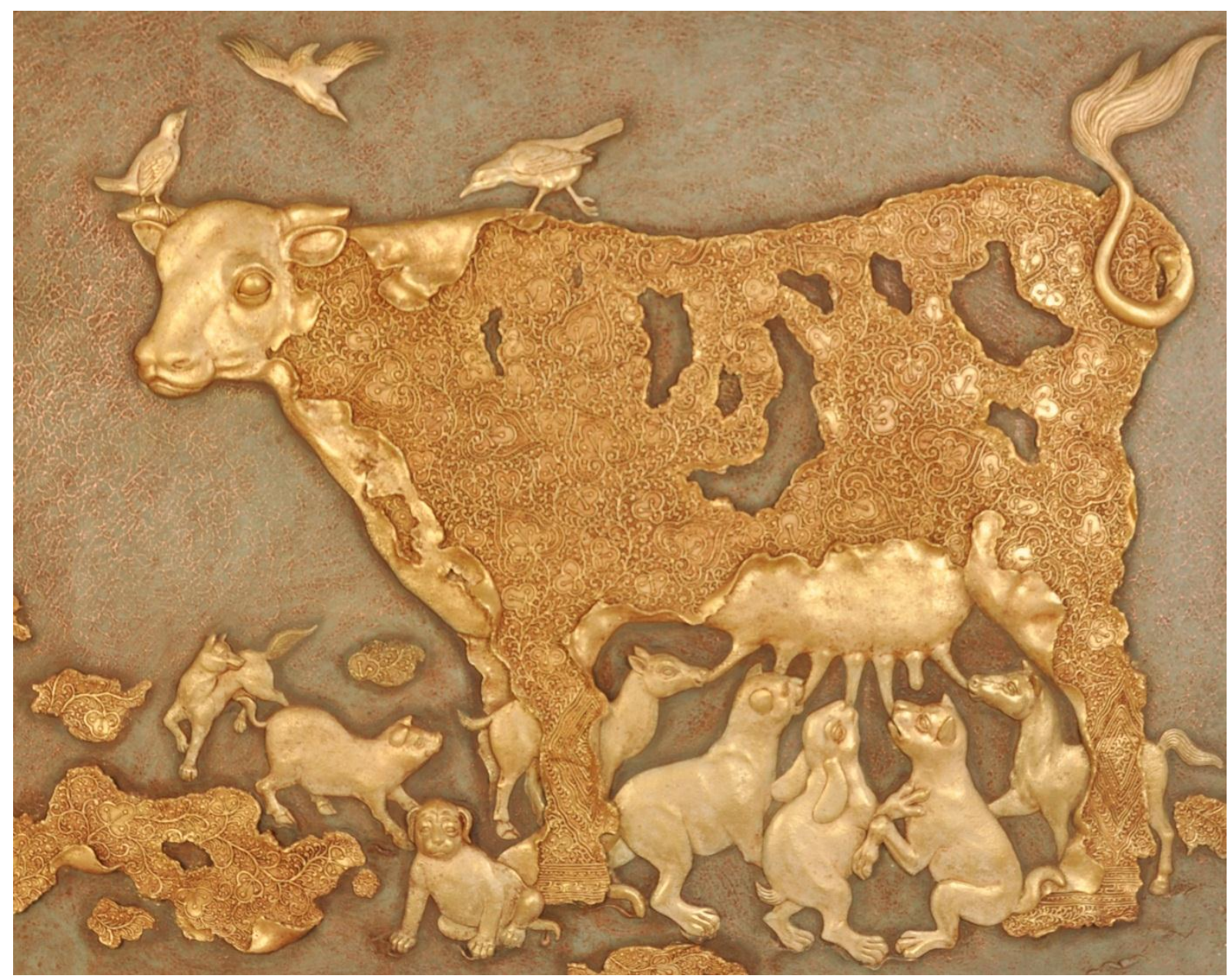

I Made Sukanadi

Ikhlas untuk Sesama

MIX MEDIA

$120 \times 140 \mathrm{~cm}$

2013 